\begin{abstract}
ARTYKULY
PAWEŁ STRÓŻYK (Uniwersytet im. Adama Mickiewicza, Poznań)
\end{abstract}

\title{
Raz jeszcze o pieczęci wielkiej miasta Sandomierza*
}

Zarys treści: Artykuł przedstawia krytyczne rozważania nad pieczęcią wielką miasta Sandomierza. Przyjąć należy, że zachowany do dziś typariusz powstał w latach 1297-1300 (może: 1292-1300), a w latach 1320-1343 został przerobiony.

Content outline: The paper presents critical considerations about the great seal of the city of Sandomierz. The conclusion is that the preserved matrix was made in 1297-1300 (maybe 1292-1300), and was redesigned during the years 1320-1343.

Słowa kluczowe: sfragistyka, typariusz, pieczęć miejska, heraldyka, herb Orzeł Biały, klejnot herbowy, Wacław II, Władysław Łokietek, Kazimierz Wielki

Keywords: sigillography, matrix, municipal seal, heraldry, White Eagle, crest, Wenceslaus II, Władysław the Short, Kazimierz the Great

Średniowieczna pieczęć miejska Sandomierza, zwana powszechnie wielką, była wielokrotnie omawiana w literaturze przedmiotu. Przypomnijmy więc pokrótce, że znamy obecnie tylko dwa jej woskowe odciski - z 1343 i 1422 r. Egzemplarz z 1343 r. został opisany przez Leona Rzyszczewskiego i Antoniego Muczkowskiego'1, a także Franciszka Maksymiliana Sobieszczańskiego ${ }^{2}$, potem zaś wydany przez Franciszka Piekosińskiego ${ }^{3}$. Odcisk z 1422 r. został opublikowany przez Przemysława Nowaka

* Artykuł stanowi uaktualnioną wersję niepublikowanego referatu prezentowanego na międzynarodowej konferencji „Ars scribendi. O sztuce pisania w średniowiecznych Czechach i Polsce", która odbyła się 15-18 IX 2008 r. w Gnieźnie. Zob. sprawozdanie H. K r z y ż o st a n i a k, W. N o w a c k i, Konferencja „Ars scribendi. O sztuce pisania w średniowiecznych Czechach i Polsce” (Gniezno, 15-18 września 2008 roku), Studia Źródłoznawcze 46, 2008, s. 207-208. Materiały z tej sesji ukazały się w: Historia Slavorum Occidentis 2012, nr 1 (2).

1 Kodeks dyplomatyczny Polski, t. I, wyd. L. Rzyszczewski, A. Muczkowski, Warszawa 1847, nr 111.

${ }^{2}$ F. M. S o bi e s z c z a ń s ki, Wiadomości historyczne o sztukach pięknych w dawnej Polsce, t. I, Warszawa 1847, s. 206.

${ }^{3}$ F. P i e k o s i ń s k i, Pieczęcie polskie wieków średnich, cz. I: Doba piastowska, Kraków 1899, nr 363, fig. 242. Uczony opublikował podobiznę jednego z kilku metalowych odlewów wykonanych z egzemplarza wiszącego przy dokumencie z 1343 r. Wcześniej graficzną 
i Piotra Pokorę 4 . Dysponujemy także zachowanym w Zbiorach XX. Czartoryskich mosiężnym typariuszem sandomierskiej pieczęci ${ }^{5}$. Podobizny egzemplarza z $1343 \mathrm{r}$. zamieszczał kilkakrotnie w swoich pracach Marian Gumowski ${ }^{6}$. Pieczęć wspominali także Marian Haisig ${ }^{7}$, Bożena Adamczyk ${ }^{8}$, Józef Szymański ${ }^{9}$, Zenon Piech ${ }^{10}$, Henryk Seroka ${ }^{11}$, Jacek Pietrzak ${ }^{12}$, Aleksandra Jaworska ${ }^{13}$ czy ostatnio Piotr Okniński ${ }^{14}$, a Mieczysław Rokosz poświęcił jej nawet monograficzny artykuł ${ }^{15}$.

podobiznę pieczęci zamieszczono w: M. B a liń s k i, T. L i p iń s k i, Starożytna Polska pod względem historycznym, jeograficznym i statystycznym opisana, t. II, Warszawa 1844, s. 269.

4 Dokumenty strony polsko-litewskiej pokoju mełneńskiego z 1422 roku, wyd. P. Nowak, P. Pokora, Poznań 2004, s. 96, nr 115 (tam barwna fotografia woskowej pieczęci). Zachowany egzemplarz pozbawiony jest większej części otoku z legendą; zachowało się tylko słowo REGIS oraz ostatnie dwie litery inskrypcji: IE.

5 Muzeum Narodowe w Krakowie, sygn. MNK-MKCz XIII-1735. Fotografię (odwróconą) płytki tłoka zamieszczono w: Insygnia miast polskich. Katalog wystawy, Poznań 1992, s. 59, il. 48. Kilka lat temu wykonano dla Muzeum Okręgowego w Sandomierzu, w technice odlewu, kopię oryginalnego tłoka przechowywanego w Krakowie. Informował o tym Tomisław Giergiel w posterze: Rekonstrukcja tłoków pieczętnych z uwzględnieniem skanowania i drukowania przestrzennego, prezentowanym na V Kongresie Mediewistów Polskich w Rzeszowie (20-24 IX 2015 r.). Zob. także T. G i e r g i e 1, Dzieje średniowiecznych pieczęci sandomierskich, Zeszyty Sandomierskie nr 35, 2013, s. 18-19.

${ }_{6}$ M. Gu m o w s ki, Najstarsze pieczęcie miast polskich XIII i XIV wieku, Toruń 1960, s. 192-193, nr 382 oraz tabl. XXX/382; t e n ż e, Handbuch der polnischen Siegelkunde, Graz 1966, tabl. LIV/578. Wcierki grafitowe badacz ten wykonał zapewne z metalowego odlewu egzemplarza z $1343 \mathrm{r}$. Bez ilustracji wzmiankował on pieczęć w podręczniku: Sfragistyka, Warszawa 1960, s. 236-237.

7 M. H a is i g, Studia nad legendą pieczęci miejskiej, Wrocław 1953, s. 113; t e n że, Herb miasta Sandomierza, Wrocław 1973 (tekst dostępny na internetowych stronach Urzędu Miejskiego w Sandomierzu: <http://bip.um.sandomierz.pl>).

${ }^{8}$ B. A d a m c z y k, Pieczęcie miast małopolskich do XV w., w: Acta Universitatis Wratislaviensis, Historia XXXIII, Wrocław 1980, s. 100, 106.

9 J. S z y mański, W sprawie genezy polskich herbów miejskich, w: Społeczeństwo Polski średniowiecznej, t. VI, Warszawa 1994, s. 174.

10 Z. P i e c h, Symbole władcy i państwa w monarchii Władysława Łokietka i Kazimierza Wielkiego, w: Imagines potestatis. Rytuały, symbole i konteksty fabularne władzy zwierzchniej. Polska X-XV w., Warszawa 1994, s. 121 oraz il. 8. Fotografia prezentuje metalowy odlew z Zakładu Nauk Pomocniczych Historii Uniwersytetu Jagiellońskiego, sygn. D 336; zob. Z. P i e c h, Zbiory odlewów pieczęci w Zakładzie Nauk Pomocniczych Historii Uniwersytetu Jagiellońskiego, w: Zbiory pieczęci w Polsce, Warszawa 2009, s. 339-376.

${ }^{11}$ J. P i e tr z a k, Średniowieczne hełmy garnczkowe na ziemiach polskich na tle zachodnioeuropejskim, Bytom 2005 (Rocznik Muzeum Górnośląskiego w Bytomiu, Archeologia 16), s. $242,311$.

12 H. S e ro k a, Herby miast małopolskich do końca XVIII wieku, Warszawa 2002, s. 32-33, fot. 7 (odlew z ZNPH UJ), s. 103-105. Zob. także t e n że, W sprawie edycji pieczęci miast dawnej Polski, w: Pieczęcie dawnej Rzeczypospolitej. Stan i perspektywy badań, Warszawa 2006, s. 290, fot. 5 (odlew z ZNPH UJ); t e n ż e, Herby miasta królewskiego Sandomierza, Sandomierz 2016, s. 10-11, fot. 8 (odlew z Muzeum Okręgowego w Sandomierzu).

13 A. J a w o r s k a, Orzeł Biały. Herb państwa polskiego, Warszawa 2003, s. 67.

14 P. Oknińs ki, Główne etapy formowania się miasta lokacyjnego w Sandomierzu w XIII-XIV wieku, Roczniki Historyczne 82, 2016, s. 96-97.

15 M. R o k o s z, Sigillum regis... et civitatis. O pieczęci wielkiej Sandomierza, w: Heraldyka i okolice, Warszawa 2002, s. 311-321 (s. 313 - fot. odlewu z ZNPH UJ). 
W polu pieczęci o średnicy $75 \mathrm{~mm}$ ukazano blankowany mur z niską basztą bramną i dwiema wysokimi basztami po bokach. W otworze lukowato sklepionego prześwitu bramnego widoczna jest uniesiona krata. Nad bramą posadowiono strażnicę o trzech otworach okiennych, nakrytą spadzistym dachem zwieńczonym sterczynami. Obydwie boczne baszty, z widocznymi po bokach wykuszami, nakryte zostały izbicami z podwójnymi otworami okiennymi. Ich dachy także zostały zwieńczone sterczynami. Ponad bramą, pomiędzy wysokimi basztami, ukazano w heraldycznym ukłonie wczesnogotycką tarczę herbową z ukoronowanym orłem, zwieńczoną hełmem garnczkowym (o widocznych rzemiennych zawiązkach) z labrami i klejnotem z piór układających się na kształt skrzydła.

$\mathrm{W}$ otoku, pomiędzy dwiema perełkowatymi liniami, znajduje się napis wykonany majuskułą gotycką: + S' - REGIS : POLOnIE - ET · CIVITATIS - SANDOMIRIE. Dwie litery mają nieregularne formy: $\mathrm{T}$ dwukrotnie oddano w kształcie właściwym dla kapitały, raz w formie półuncjalnej, natomiast kapitałowe $\mathrm{N}$ współwystępuje w legendzie napieczętnej z literą o kształcie zaczerpniętym z minuskuły. Kontrowersyjne jest rozwinięcie początkowego S'. Większość badaczy przyjęła, że chodzi o obcięte słowo SIGILLVM, jednak takie rozwiązanie skrótu nie przekonało Józefa Szymańskiego, który sam zaproponował w to miejsce wyraz SIGNUM lub SIGNA ${ }^{16}$.

Skoro najstarszy zachowany odcisk pieczęci wisi przy dokumencie z 1343 r., rok ten uznano za terminus ante quem sporządzenia typariusza. Widniejący w polu pieczęci ukoronowany orzeł w gotyckiej tarczy, będący herbem Królestwa Polskiego, mógł zostać wyobrażony na pieczęci dopiero po koronacji Władysława Łokietka, a zatem najwcześniej w $1320 \mathrm{r}$. W literaturze przyjęto więc zgodnie, że powstanie pieczęci musiało przypaść na lata 1320-1343. M. Gumowski uznał, że wyobrażony hełm z klejnotem może odnosić się tylko do Władysława Łokietka, powtarza się bowiem na jego książęcej pieczęci z 1314 r. oraz na jego denarach krakowskich. Przyjął on, że pieczęć powstała w czasie zbliżonym do koronacji Łokietka ${ }^{17}$. Stanowczości tego sądu nie podzielił jednak M. Rokosz, który podkreślił, że obydwa klejnoty - ten z pieczęci książęcej Łokietka oraz ten z pieczęci miejskiej Sandomierza - przedstawione w postaci bogatych pióropuszy wieńczących hełmy, nie są do siebie podobne, ozdoby zaś tego typu pojawiły się także na kilku innych pieczęciach książęcych z XIV w. ${ }^{18}$ Wcześniej F. Piekosiński łączył powstanie pieczęci z wydanym dla Sandomierza przywilejem Kazimierza Wielkiego z 1336 r., regulującym kwestie jurysdykcji miejskiej ${ }^{19}$. Także M. Rokosz opowiedział się za datowaniem pieczęci na początkowe lata panowania Kazimierza Wielkiego - między 1333 a 1343 rokiem -

${ }^{16}$ J. S z y m án s k i, W sprawie genezy, s. 174, przyp. 28.

17 M. Gu mow ski, Najstarsze pieczęcie, s. 192-193. Pieczęć Władysława Łokietka reprodukował F. Pi ek o s iński, Pieczęcie, nr 306, fig. 200. Zob. także Z. P i e c h, Ikonografia pieczęci Piastów, Kraków 1993, s. 217-218, fot. 31; M. H le b i o n e k, Pieczęcie Piastów kujawskich, Inowrocław 2011, s. 74 (nr 10). Literaturę o denarach Łokietka zestawiam w przyp. 33.

${ }_{18}$ M. R o k o s z, Sigillum, s. 317, z odesłaniem do pracy F. P i e k o s iń s k i e g o, Pieczęcie, nr 210, fig. 156, nr 315, fig. 206 oraz nr 346, fig. 228 (pieczęcie Wacława II króla czeskiego, księcia krakowskiego i sandomierskiego; Władysława księcia oświęcimskiego oraz Przemysła księcia sieradzkiego).

19 F. Pi e k os ińs ki, Pieczęcie, s. 212 (nr 363). 
uznając, że jest ona „swoistym znakiem polityki miejskiej króla Kazimierza i jego sojuszu z miastami”. Stwierdził przy tym, że pieczęć przedstawia obraz miasta wyprzedzający może „,wieloletni proces lokacyjno-budowlano-fortyfikacyjny” i będący „jakby jego projekcją" ${ }^{20}$. Inaczej motyw murów postrzegał H. Seroka, widząc w nich wyobrażenie odnoszące się do sandomierskiego zamku królewskiego ${ }^{21}$, samą zaś pieczęć datował na czas po koronacji Łokietka (1320), dopuszczając też możliwość jej wykonania po koronacji Kazimierza Wielkiego (1333) 22 .

Napieczętny motyw heraldyczny łączy się treściowo z początkowym fragmentem inskrypcji, który podkreślał królewską współwłasność rzeczonej pieczęci (S. REGIS POLOnIE). Pieczęć sandomierską traktować należy bowiem - jak podkreślał M. Rokosz - ,jako signum króla Polski i całego miasta"23. H. Seroka uznał, że niezwykła legenda napieczętna wiązała się zapewne z ograniczeniem roli dziedzicznego wójta sandomierskiego z powodu wsparcia, którego udzielił on przeciwnikom Łokietka w czasie buntu wójta Alberta w Krakowie. Łokietek, przywracając w 1311 r. wójtostwo synom wójta Marka, zaznaczył swoje zwierzchnictwo nad miastem, zastrzegając sobie prawo rocznego dochodu w wysokości 200 grzywien. Wykonanie zatem nowej pieczęci należałoby wiązać - zdaniem H. Seroki - przede wszystkim z chęcią ukazania dominującej pozycji władcy nad miastem ${ }^{24}$, a więc de facto ze względami propagandowymi.

Na pieczęci sandomierskiej - co zgodnie przyjęli badacze - wyobrażono tarczę z królewskim orłem, zwieńczoną klejnotem w kształcie skrzydła, zapewne orlego ${ }^{25}$. Zauważmy jednak, że klejnot polskiego herbu miał charakter tautologiczny i przedstawiał orła, zwykle - choć nie zawsze - z rozpostartymi skrzydłami ${ }^{26}$. Najstarsze zachowane przedstawienia polskiego klejnotu w kształcie orła znamy z drugiej połowy XIV w. (herb na zewnętrznej stronie prezbiterium kościoła Mariackiego w Krakowie ${ }^{27}$; herb na zworniku w kościele w Stopnicy ${ }^{28}$; herb w nadłuczu portalu

${ }^{20}$ M. R o k o s z, Sigillum, s. 318-319.

${ }^{21}$ H. S e roka, Herby miast małopolskich, s. 32-33, 104-105; t e n ż e, Herby miasta królewskiego, s. 11, uznał jednak, że pieczęć wyobraża „mury obronne”.

${ }^{22}$ Te n ż e, Herby miast małopolskich, s. 32; t e n ż e, Herby miasta królewskiego, s. 11.

${ }^{23}$ Zob. M. R o k o s z, Sigillum regis, s. 315. Stwierdzenie B. A d a m c z y k, Pieczęcie, s. 100, jakoby napis otokowy oznaczał, ,że pieczęć Sandomierza należy do Królestwa Polskiego", uznać należy za nieprecyzyjne.

${ }^{24}$ H. S e r o k a, Herby miast małopolskich, s. 32-33.

25 F. P i e k o s i ń s k i, Pieczęcie, s. 211 (nr 363), uznał, że hełm zwieńczony został ,pióropuszem pawim w kształcie skrzydła". Za nim powtórzył to M. R o k o s z, Sigillum, s. 313.

${ }_{26}$ Zob. A. Zn a mi e row s ki, Elementy herbu polskiego 1295-1995, w: Orzeł Biały. Herb państwa polskiego, Warszawa 1996, s. 86-88, fot. 3-6; A. J a w o r s k a, Orzeł Biały, s. 204-210 (rozdz.: Klejnot herbu Orzeł Biały). Zob. także A. N a d o 1 s k i, Uroczysty strój rycerski królów polskich w XIV-XV wieku, Kwartalnik Historii Kultury Materialnej 21, 1973, nr 2, s. 305-313.

${ }_{27}$ T. W ę c ła w o w i c z, Dekoracja figuralna prezbiterium kościoła Mariackiego w Krakowie a zagadnienie mecenatu Mikołaja Wierzynka Starszego, Rocznik Krakowski 56, 1990, s. 234; E. P i w o w a r c z y k, Mieszczańska „katedra”. Patronat nad kościołem Mariackim w średniowieczu, Nasza Przeszłość 97, 2002, s. 42-43; A. J a w o r s k a, Orzeł Biały, s. 208, il. 39; M. Wa l c z a k, Rzeźba architektoniczna w Małopolsce za czasów Kazimierza Wielkiego, Kraków 2006, s. 181-182, fot. 134.

${ }_{28}$ M. Wa l c z a k, Rzeźba, s. 319, 322, fot. 280. 
kolegiaty wiślickiej ${ }^{29}$; herb na zworniku w sali frontowej tzw. Kamienicy Hetmańskiej przy Rynku Głównym 17 w Krakowie ${ }^{30}$; herbowa zapona z czasów Ludwika Węgierskiego $^{31}$ ). Tymczasem na pieczęci sandomierskiej klejnot wieńczący hełm przybrał formę pióropusza w kształcie skrzydła, temu więc zagadnieniu musimy poświęcić nieco uwagi, stawiając tu pytanie: czy tarczę z Orłem Białym w polu miejskiego sigillum na pewno zwieńczono właściwym klejnotem?

M. Gumowski wskazał wprawdzie, że klejnot wyobrażony na pieczęci sandomierskiej podobny jest do tego, który widnieje na pieszej pieczęci książęcej Władysława Łokietka, nad tarczą z jego herbem kujawskim, a także do tego, który znalazł się na hełmie przedstawionym na denarach krakowskich tego władcy, poprzestał jednak na samym wskazaniu ikonograficznych analogii i nie objaśnił powodu, dla którego takim właśnie klejnotem zwieńczono orła na pieczęci sandomierskiej ${ }^{32}$. B. Paszkiewicz uznał, że orle skrzydło zdobiące hełm na wspomnianych denarach Łokietka to „element herbu Orzeł Biały: jego klejnot” i ,jedyny znany przykład umieszczenia klejnotu heraldycznego na polskiej monecie królewskiej"33. Za tym badaczem podążyła także A. Jaworska, uznając klejnot w formie orlego skrzydła za element zewnętrzny herbu Orzeł Biały, czego przykładem byłyby nie tylko Łokietkowe denary, ale także pieczęć sandomierska ${ }^{34}$. P. Okniński przyjął, że „hełm z pióropuszem został zapewne przejęty z repertuaru znaków władzy Władysława Łokietka”, skoro widzimy go na jego pieczęci pieszej oraz na denarach emitowanych po 1320 r. ${ }^{35}$ Wcześniej H. Seroka zadowolił się konstatacją, że na pieczęci sandomierskiej mamy do czynienia z „pióropuszem zwieńczonym rzędem lilii (?)”, który jest heraldycznym klejnotem ukazanego herbu $^{36}$, inni zaś autorzy (M. Rokosz, Z. Piech) pominęli tę kwestię milczeniem ${ }^{37}$.

29 Tamże, s. 294-295, fot. 250-251, 253.

${ }^{30}$ M. W a 1 c z a k, Dekoracja heraldyczna pałacu przy Rynku Głównym 17 w Krakowie, Folia Historiae Artium, seria nowa 10, 2005, s. 59-88; t e n ż e, Rzeźba architektoniczna, s. 246, 267, fot. 217 (tam zebrana literatura przedmiotu).

31 E. Ś n i ė̇yńska-S tolot, Andegaweńskie dary złotnicze z herbami polskimi w Kaplicy Węgierskiej w Akwizgranie, Folia Historiae Artium 11, 1975, s. 28-29; Orzeł Biały - 700 lat herbu państwa polskiego, Warszawa 1995, s. 90 (fot. 23) oraz s. 231 (kat. II 5);

A. Zn a mi e row s k i, Elementy herbu, fot. 5.

32 M. G u m o w s ki, Najstarsze pieczęcie, s. 193.

33 B. P a s z k i e w i c z, Od symbolu do herbu. Orły polskie na monetach średniowiecznych, w: Orzeł Biały (jak w przyp. 26), s. 26. Zagadnienie mennictwa czasów Władysława Łokietka było przedmiotem licznych publikacji tego autora: t e n ż e, Mennictwo Władysława Łokietka, Wiadomości Numizmatyczne 30, 1986, z. 1-2 (monograficzny), s. 85-86 (tu mniej stanowczo: „symbolika hełmu natomiast jest niejasna. Być może hełm z klejnotem w kształcie orlego skrzydła należy uważać za element zewnętrzny herbu kujawskiego"); t e n ż e, Denary krakowskie Władysława Łokietka - uzupełnienia, tamże 36, 1992, z. 3-4, s. 131-147; t e n ż e, Denar Władysława Łokietka z tarczą, tamże 46, 1994, z. 1, s. 67-73; t e n ż e, Kraków, Sandomierz i mennictwo Władysława Łokietka, w: Miasta, ludzie, instytucje, znaki. Księga jubileuszowa ofiarowana Profesor Bożenie Wyrozumskiej w 75. rocznicę urodzin, Kraków 2009, s. 765-778.

34 A. J a w or s k a, Orzeł Biały, s. 66-67; t e j ż e, Konotacje herbu Orzeł Biały w sfragistyce monarchów z dynastii Piastów i Jagiellonów (1295-1572), w: Pieczęć w Polsce średniowiecznej i nowożytnej. Zbiór studiów, Lublin 1998, s. 130.

35 P. O kn iń s k i, Główne etapy, s. 97.

${ }^{36}$ H. S e r o k a, Herby miast małopolskich, s. 32; t e n ż e, Herby miasta królewskiego, s. 11.

37 Zob. M. R o k o s z, Sigillum, s. 313, 315; Z. P i e c h, Symbole, s. 118-121, 135-136. 
Zauważmy zatem, że badacze - wbrew wymowie przekazów z drugiej połowy XIV w. - przyjęli de facto ów klejnot za formalny element herbu Orzeł Biały, a pieczęć sandomierską za egzemplifikację takiego stanu rzeczy. Wobec tego albo przychylimy się do poglądu, że 1) przed wykształceniem się tautologicznego klejnotu herbu Orzeł Biały istniał inny, starszy herbowy klejnot - w formie orlego skrzydła - z którego zrezygnowano na rzecz wzbijającego się do lotu orła, albo uznamy, że 2) orle skrzydło obecne wśród znaków używanych przez Władysława Łokietka i ewentualnie Kazimierza Wielkiego było zewnętrznym elementem ich herbu kujawskiego (rodowego), który w połączeniu z Orłem Białym na pieczęci miejskiej Sandomierza przyniósł nam wizerunek heraldycznej hybrydy, niepotwierdzonej żadnym innym przekazem obrazowym, albo też 3) potraktujemy hełm z klejnotem w kształcie orlego skrzydła jako osobisty znak władcy ${ }^{38}$, który nie będąc stałym elementem składowym żadnego konkretnego herbu, mógł być doraźnie i wymiennie łączony z dwoma różnymi herbami: książęcym-kujawskim lub królewskim-polskim (przykładem byłyby pieczęcie: Łokietka z 1314 r. i sandomierska z lat 1320-1343). W tym ostatnim jednak przypadku musielibyśmy założyć, że obydwa wymienione herby nie miały jeszcze wówczas ukształtowanych klejnotów.

Spróbujmy odnieść się do powyższych możliwości, rozpoczynając od pieszej pieczęci książęcej Władysława Łokietka, znanej z odcisku z 1314 r. Przedstawia ona stojącego władcę, po bokach którego umieszczone są dwie tarcze herbowe z prawej (heraldycznie) z ukoronowanym orłem w lewo, a z lewej (heraldycznie) z godłem książąt kujawskich. Ten ostatni herb zwieńczony jest hełmem z klejnotem-pióropuszem w kształcie skrzydła. Gdyby przedstawiony na pieczęci hełm potraktować jako ,nieheraldyczny”, osobisty znak Łokietka, który doraźnie tylko skonfigurowano z herbem kujawskim, to - pomijając wszelkie zastrzeżenia natury heraldycznej - musielibyśmy zapytać, dlaczego owo osobiste insygnium nie zwieńczyło ideowo ważniejszego herbu - herbu Królestwa Polskiego (umieszczonego po prawej stronie władcy i wyobrażonego także na trzymanej przez księcia chorągwi). Byłoby to rozwiązanie ideowo najwłaściwsze. Skoro jednak nie zdecydowano się na nie, to przyczyna mogła być tylko jedna - hełm z klejnotem nie pełnił na pieczęci roli osobnego, książęcego insygnium, lecz był zewnętrznym elementem herbu książąt kujawskich. A skoro tak, to analogicznie musimy postrzegać hełm z klejnotem obecny

38 Z. P i e c h, Symbole, s. 135-136, wskazywał, że - wykorzystywany przede wszystkim przez książąt - „hełm z klejnotem można interpretować albo jako element heraldyczny, albo jako insygnium bądź symbol władzy”. Zob. t e n ż e, Strój, insygnia i atrybuty książąt piastowskich do końca XIV wieku (cz. II), Kwartalnik Historii Kultury Materialnej 38, 1990, nr 3-4, s. 199-202; t e n ż e, Ikonografia, s. 61-63. W zagadnienie funkcjonowania klejnotu wprowadza J. M i c h t a, Klejnot w herbach w średniowieczu i okresie nowożytnym, w: Venerabiles, nobiles et honestii. Studia z dziejów społeczeństwa Polski średniowiecznej. Prace ofiarowane Profesorowi Januszowi Bieniakowi w siedemdziesiątą rocznicę urodzin i czterdziestopięciolecie pracy naukowej, Toruń 1997, s. 341-349. Zob. też A. H e y m o w s k i, Les cimiers médiévaux des blasons polonais, w: Recueil du IX ${ }^{\mathrm{e}}$ Congrès international des sciences généalogiques et héraldiques, Berne 1968, s. 131-141; t e n ż e, Les cimiers médiévaux de la chevalerie polonaise, w: Le cimier mythologique, rituel, parenté des origines au XVI' siècle, Bruxelles 1990, s. 79-97; S. K. K u c z y ń s ki, Les cimiers territoriaux en Pologne médiévale, w: tamże, s. 169-179; J. S z y m a ń s k i, Herbarz średniowiecznego rycerstwa polskiego, Warszawa 1993, s. 48-60. 
na denarach królewskich Władysława Łokietka (typ 3) ${ }^{39}$. W innym bowiem razie musielibyśmy przyjąć, że albo herb Orzeł Biały miał wówczas taki sam lub bardzo podobny klejnot, do tego, jaki miał herb kujawski (a to przecież wprowadzałoby niepożądany zamęt w systemie znaków królewsko-państwowych), albo że klejnot, stanowiący zewnętrzny element herbu kujawskiego, mógłby w pewnych okolicznościach (ukazany osobno), tracić swoje heraldyczne znaczenia i konotacje, stając się znakiem-insygnium władcy, który na dodatek nie był już wtedy księciem, lecz królem. Takie jednak spekulowane możliwości w ogóle nie przekonują. Ponadto przekonanie o „kujawskości” klejnotu Władysława Łokietka wzmacnia fakt używania podobnych w formie klejnotów przez innych Piastów kujawskich. Widnieją one na sieradzkiej pieczęci herbowej Przemysła Ziemomysłowica ${ }^{40}$ oraz takowej księcia gniewkowskiego Władysława Białego ${ }^{41}$. Wskażmy także nieznaną do niedawna, beznapisową monetę odkrytą w skarbie z Hrabušic, która przedstawia z jednej strony godło herbowe książąt kujawskich (połulew-połuorzeł bez korony), z drugiej zaś - hełm zwieńczony klejnotem w formie orlego skrzydła, o której B. Paszkiewicz napisał, że „mamy tu do czynienia najprawdopodobniej z bliżej nieokreśloną polską monetą regionalną z czasów Kazimierza Wielkiego, niewykluczone, że mającą związek z którymś z drobniejszych dynastów kujawskich podporządkowanych temu królowi"42.

Musimy zatem przyjąć, że zarówno w przypadku pieczęci książęcej Władysława Łokietka, jak i jego królewskich denarów z hełmem wyobrażony klejnot był elementem

${ }^{39} \mathrm{~W}$ podtypie napisowym (3/I) na awersie obok hełmu z klejnotem w kształcie orlego skrzydła widnieje legenda: M[ONETA] REGIS (przy czym początkowe M przybrało postać litery N), na rewersie zaś obok orła słowo: POLONIE. Początek emisji królewskich denarów Władysława Łokietka typu 3 (z podtypami napisowym i beznapisowym) datowany był do niedawna na 1320 r., obecnie zaś czas ich produkcji zamykany jest latami 1326-1333, zob. B. P a s z k i e w i c z, Mennictwo, s. 32-35, 53-57; t e n ż e, Kraków, Sandomierz i mennictwo, s. 778. Jak słusznie zauważył M. Wa l c z a k, Rzeźba, s. 258: „umieszczenie hełmu razem z początkiem inskrypcji na awersie każe odnosić ten znak do samego władcy i wywodzić go z tradycji heraldycznej książąt kujawskich". Należy zgodzić się z tym poglądem, przyjmując, że denary z hełmem prezentowały dwa odrębne znaki, odnoszące się do odmiennych treści. Przypomnijmy, że Władysław Łokietek i Kazimierz Wielki także na swoich dwustronnych, majestatycznych pieczęciach umieścili dwa różne elementy heraldyczne: po jednej stronie wyobrażenie tronującego władcy z książęcym herbem kujawskim u stóp, po drugiej zaś - wizerunek ukoronowanego orła (F. P i e k o s i ń s k i, Pieczęcie, s. 189-191, nr 320-321, fig. 209-210 oraz s. 217-220, nr 377-378, fig. 251-252; Z. P i e c h, Ikonografia, s. 252-253, gdzie dalsza literatura). Na kujawską interpretację klejnotu wskazuje też ujawniony kilka lat temu typ denara Władysława Łokietka (z godłem kujawskim na awersie i hełmem z klejnotem w kształcie pióropusza na rewersie), datowany wstępnie na książęcy okres jego władzy w Krakowie (1306-1320), zob. B. P a s z k i e w i c z, Nieznany denar książęcy Władysława Łokietka, Wiadomości Numizmatyczne 54, 2010, z. 1, s. 87-89.

40 F. P i e k o s iń s k i, Pieczęcie, s. 203-204, nr 346, fig. 228; M. H 1 e b i o n e k, Pieczęcie, s. 27, 60-63, 84; fot. 16, 31d. Pieczęć datowana na lata 1330-(1335?).

${ }^{41}$ F. P i e k o s i ń ski, Pieczęcie, s. 242, nr 437; M. H le b i o n e k, Pieczęcie, s. 29, 60-63, 85; fot. 18, 31e (pieczęć datowana na lata 1353-1369?).

42 B. P a s z k i e w i c z, De moneta in Regno currente. Mennictwo polskie Kazimierza Wielkiego, Roczniki Historyczne 74, 2008, s. 41-42, fot. 12 a-b. Osobną kwestią pozostaje atrybucja kwartnika z herbem kujawskim i hełmem z klejnotem, wyobrażonych po dwóch stronach monety (t e n ż e, Mennictwo, s. 79-80). 
rozbudowanego książęcego herbu kujawskiego. Tym samym nie możemy postrzegać klejnotu o kształcie orlego skrzydła ani jako książęcego insygnium o nieheraldycznych funkcjach, ani jako heraldycznego klejnotu Orła Białego. O tym, że orle skrzydło nie pełniło funkcji klejnotu w herbie Orzeł Biały ani nie zostało wtórnie zastąpione klejnotem tautologicznym, dobitnie świadczy także to, że obydwa te znaki (orle skrzydło i ukoronowany orzeł podrywający się do lotu) umieszczono na hełmach dekorujących zworniki w tzw. Kamienicy Hetmańskiej, w ramach jednego programu heraldycznego ${ }^{43}$. Herb Orzeł Biały jest tam reprezentowany przez hełm zwieńczony klejnotem tautologicznym, a zatem hełm z klejnotem w kształcie orlego skrzydła musiał reprezentować inny herb, zapewne - na co słusznie wskazywał Z. Piech należący do linii Piastów kujawskich ${ }^{44}$.

Jedynym zatem znanym nam przykładem wykorzystania hełmu z klejnotem w kształcie orlego skrzydła ponad tarczą z Orłem Białym pozostaje interesująca nas pieczęć miejska Sandomierza. Odrzuciliśmy możliwość uznania orlego skrzydła za przejściową formę klejnotu Orła Białego, wykorzystywaną do czasu wykształcenia się klejnotu tautologicznego, taka bowiem praktyka niewątpliwie wprowadzałaby chaos w system symboli władcy i państwa. Jak więc wytłumaczyć owo hybrydowe - gdyż tylko tak (w świetle powyższych uwag) należy je traktować - połączenie Orła Białego z klejnotem należącym do innego herbu? I czy był nim, jak wskazywali niektórzy badacze, herb książąt kujawskich?

Otóż niekoniecznie. Jeśli uważnie przypatrzeć się budowie klejnotu herbowego, to można dostrzec pewien charakterystyczny szczegół ikonograficzny, który uchodził należnej uwadze uczonych - rząd siedmiu drobnych elementów o sercowatym kształcie. To zapewne lipowe listki, obecne w heraldyce władców czeskich z dynastii

${ }^{43}$ M. Wa l c z a k, Rzeźba, s. 238, 246, fot. 217, 223.

44 Z. P i e c h, rec., Kwartalnik Historyczny 102, 1995, s. 101-102 (klejnot odniósł do Elżbiety Łokietkówny). Jak uznał F. P i e k o s i ń s k i, Sala gotycka w kamienicy Hetmańskiej w Krakowie, Rocznik Krakowski 1, 1898, s. 4, orle skrzydło reprezentuje ogół rycerstwa (zob. także t e n ż e, O sali gotyckiej w kamienicy Hetmańskiej w Krakowie, tamże 9, 1907, s. 225-226), co przyjął L. K a j z e r, Uzbrojenie i ubiór rycerski w średniowiecznej Małopolsce w świetle źródeł ikonograficznych, Wrocław-Warszawa 1976, s. 113, choć wcześniej łączył ten znak z faktem posiadania ziemi sieradzkiej przez Kazimierza Wielkiego (t e n ż e, Jeszcze o Sali gotyckiej w domu przy Rynku Głównym 17 w Krakowie, Biuletyn Historii Sztuki 36, 1974, z. 4, s. 364). Ku temu ostatniemu poglądowi skłaniali się także P. S k u b i s z e w s k i, Die Schlusssteine des Saales im Krakauer Haus Marktplatz 17, w: Die Parler und der Schöne Stil 1350-1400. Europäische Kunst unter den Luxemburgen. Ein Handbuch zur Ausstellung des Schnütgen-Museums in der Kunsthalle Köln, t. II, Köln 1978, s. 438, oraz wydawcy Katalogu zabytków sztuki w Polsce, t. IV, z. 10, Warszawa 2005, s. 72, przyp. 241. Z kolei S. K. K u c z y ń s k i, Polskie herby ziemskie. Geneza, treści, funkcje, Warszawa 1993, s. 58, przyp. 22, traktując orle skrzydło jako pars pro toto Orła Białego, dostrzegł w nim możliwość reprezentowania króla, Królestwa, ziemi krakowskiej, a może nawet ziemi poznańskiej. M. W a l c z a k, Rzeźba, s. 259, 353, idąc za Z. Piechem, odniósł klejnot do kujawskiej linii Piastów, ale łączył go jednak z osobą Kazimierza Wielkiego. Problematykę herbu Piastów kujawskich omówili Z. P i e c h, Uwagi o genezie i symbolice herbu książąt kujawskich, Studia Historyczne 30, 1987, z. 2, s. 175-190, oraz B. P a s z k i e w i c z, Król Otokar i Piastowie: pochodzenie herbu kujawskiego w świetle monet i pieczęci, w: Historia u Piastów. Piastowie w historii. Z okazji trzechsetlecia śmierci ostatniej z rodu, księżnej Karoliny, Brzeg 2008, s. $113-126$. 
Przemyślidów, a potem Luksemburgów. Zagadnienia związane z klejnotem czeskiego herbu omówił osobno Vladimír Sedlak ${ }^{45}$, który przyjął, że klejnotem herbowym władców czeskich było orle skrzydło. Po raz pierwszy zostało ono wyobrażone na pieczęci Przemysła Ottokara II (1253-1278), wykonanej z okazji jego koronacji w $1261 \mathrm{r}^{46}$, potem zaś widniało na wszystkich kolejnych pieczęciach tego władcy ${ }^{47}$. Jego syn i następca, Wacław II, ozdobił klejnot herbowy złotymi lipowymi listkami, nie znalazły one jednak swojego odzwierciedlenia na jego pieczęciach ${ }^{48}$. Klejnot z takimi ozdobami znalazł się na miniaturze przedstawiającej tronującego króla Wacława ze słynnego heidelberskiego rękopisu, znanego jako Codex Manesse ${ }^{49}$. Po prawej stronie władcy widoczny jest herb czeski, zwieńczony hełmem z labrami i klejnotem ozdobionym dwoma rzędami złotych lipowych listków. Po Przemyślidach klejnot $\mathrm{w}$ formie orlego skrzydła przejęli Luksemburgowie. Należy jednak wspomnieć, że początkowo nie zawsze złote lipowe listki pojawiały się w ikonografii herbu czeskiego - niekiedy klejnot przedstawiany był bez tego charakterystycznego elementu. Lipowe listki są widoczne na pieczęci konnej króla Jana Luksemburskiego z lat dwudziestych XIV w., a także na jednej z jego pieczęci sekretnych, ale nie ma ich na innych pieczęciach tego władcy ${ }^{50}$. Ów ozdobny element występował także w heraldyce rycerskiej w Czechach, nie tylko zdobiąc klejnoty rycerskie w kształcie orlego skrzydła, ale także klejnoty o innym kształcie (np. rogi) ${ }^{51}$. Lipowe listki widnieją też na pochodzących z początków XIV w. pieczęciach niektórych miast, jeśli te umieszczały na swoich typariuszach herb czeski z klejnotem (Kutná Hora, Slaný $)^{52}$. Od lat trzydziestych XIV w. złote lipowe listki stały się już regularnym elementem czeskiego herbu, o czym świadczą barwne wizerunki m.in. na zachowanym stole z Lüneburga z ok. 1330 $0^{53}$, w zuryskiej roli herbowej (Zürcher Wappenrolle) z lat 1330-1340 54 , we flamandzkim herbarzu herolda Geldrii (Wapenboek Gelre) z lat

45 V. J. S e d l a k, O klenotu českého znaku, Rodokmen 1, 1946, z. 1, s. 2-4, z. 2, s. 44-47.

46 J. Č a r e k, O pečetech českých knížat a králů z rodu Přemyslova, Sborník příspěvků k dějinám hlavního města Prahy 8, 1938, s. 14-15; J. H o molk a, K ikonografii pečetí posledních Přemyslovců, w: Umění doby posledních Přemyslovců, Praha 1982, s. 166-167.

47 J. Č a r e k, O pečetech, s. 15-17, tab. 6; J. H o m o l k a, K ikonografii, s. 166-175, fot. $119,122-123,124-125$.

48 J. Č a r e k, O pečetech, s. 17-19, tab. 7-8; J. H o m olk a, K ikonografii, s. 175-178, fot. $127-128$.

49 L. J a n, Václav II. Král na střibrném trůnu 1283-1305, Praha 2015, fot. 4 (barwna); A. Z n a mi erow ski, P. D u d zi ń ski, Wielka księga heraldyki, Warszawa 2008, fot. na s. 65 .

${ }^{50}$ Die Siegel der deutschen Kaiser und Könige von 751 bis 1806, wyd. O. Posse, t. I, Dresden 1909, s. 26-27, tabl. 48-49; t. V, Dresden 1913, s. 36. Zob. także K. M a rá z, Pečeti Jana Lucemburského, Brno 2007, passim (sekretu nie wspomniał wcześniej V. J. S e d la k, O klenotu, ani O. Posse, Die Siegel).

${ }^{51}$ Liczne przykłady zestawił V. J. S e d 1 a k, O klenotu, s. 4, 44-45.

52 Tamże, s. 45; zob. także J. Č a r e k, Městské znaky v českých zemích, Praha 1985, s. 348.

53 O. N e u becke r, Heraldry: Sources, Symbols and Meaning, London 1997, s. 85, 154-155.

54 Tamże, s. 85; M. P a s t o u r e a u, L'art héraldique au Moyen Âge, Paris 2009, s. 123; A. S e d lá č e k, Atlasy erbů a pečetí české a moravské středověké šlechty, t. II, Praha 2001, s. 296,467 , tabl. $19 b$. 
1369-1396 $6^{55}$ czy też w miniatorskich dekoracjach ksiąg z biblioteki króla Wacława IV $(1378-1419)^{56}$. Spośród licznych realizacji rzeźbiarskich wskażmy przykładowo na tympanon z ratusza we Wrocławiu ${ }^{57}$.

Czy to możliwe jednak, żeby na pieczęci sandomierskiej widniał klejnot królów czeskich, chociaż w tarczy herbowej przedstawiono ukoronowanego orła? Napis wszak jednoznacznie odnosi wyobrażenie heraldyczne do króla polskiego: S' REGIS POLOnIE, (nie zaś BOEMIE). Autopsja tłoka pieczętnego nie ujawnia bezpośrednio zachowanych śladów wtórnej ingerencji rytownika, pozwala jednak na dokonanie pewnych spostrzeżeń, które wskazują na możliwość przerabiania inskrypcji ${ }^{58}$. Wydaje się, że w miejscu obecnego słowa POLOnIE umieszczone było pierwotnie słowo BOEMIE. Aktualizując tłok, wystarczyło tylko usunąć z legendy litery EM i na to miejsce wstawić litery LOn, a także zmienić początkowe B na P. Takie drobne przeróbki nie stanowiły zapewne większego wyzwania dla biegłego złotnika. Jeśli przypatrzymy się dokładnie tłokowi, zauważymy, że litery OL w słowie POLOnIE są umieszczone bardzo blisko siebie, nie zachowując przeciętnego światła między pozostałymi literami całej legendy napieczętnej. W stosunku do innych liter inskrypcji litery LO w słowie POLOnIE za bardzo schodzą ku perełkowej linii oddzielającej inskrypcję od wyobrażenia napieczętnego. W słowie tym zastosowano też (choć często zdarzało się to w inskrypcjach) półuncjalną literę n, różniącą się od kapitałowej litery $\mathrm{N}$ w słowie SANDOMIRIE. Zauważmy także, że $\mathrm{n}$ nieco za bardzo pochyla się w stronę litery O. Litera I w słowie POLOnIE pozbawiona jest części dolnego szeryfu od strony poprzedzającej litery. W całej inskrypcji tylko raz, w słowie REGIS, szeryf od litery I złączył się z sąsiednią literą (S), w pozostałych zaś pięciu przypadkach szeryfy są całe i dobrze widoczne (słowa: CIVITATIS SANDOMIRIE). Odstępy między literami w słowie POLOnIE nie są jednakowe. Gdyby zamiast liter LOn wstawić litery M (która w słowie SANDOMIRIE ma szerokość $8 \mathrm{~mm}$ ) oraz E

${ }^{55}$ O. N e u b e c k e r, Heraldry, s. 85; A. S e d l á č e k, Atlasy erbů, t. II, s. 295, 466-467, tabl. 19a.

56 A. Ë̈r s i, Gotyk międzynarodowy, Warszawa 1986, il. 16 (karta tytułowa wykonanej w 1400 r. kopii Złotej Bulli Karola IV); K. C s a p o d i - G á r d o n y i, Iluminowane kodeksy europejskie, Wrocław 1984, tabl. 73 (karta kodeksu z komentarzami do Ptolemeusza, przełom XIV i XV w.); J. K rá s a, Rukopisy Václava IV, Praha 1974, fot. kolorowe nr: 3-5, 15; fot. czarno-białe nr: 8, 10, 12, 23-24, 28, 74, 102, 120.

57 R. K a c z m a r e k, Portal z tympanonem w fasadzie wschodniej ratusza we Wrocławiu. Przyczynek do ikonografii lwa w hełmie, w: Nobile claret opus. Studia z dziejów sztuki dedykowane Mieczysławowi Zlatowi, Wrocław 1998, s. 95-105, fot. 1-2. Dalsze rzeźbiarskie realizacje wylicza V. J. S e d la k, O klenotu, s. 46.

58 Oględzin typariusza dokonałem w Muzeum XX. Czartoryskich w Krakowie, 8 IX 2008 r., dzięki uprzejmości Pani kustosz Katarzyny Kopery-Banasik z Działu Rzemiosła Artystycznego. Obserwacje te można też poczynić na zachowanych odlewach, wykonanych z egzemplarza pieczęci z 1343 r. (stopień zniszczenia woskowego odcisku z 1422 r. nie daje takich możliwości), jednak bezpośredni ogląd tłoka pozwala uniknąć jakichkolwiek wątpliwości powodowanych obawą ewentualnej utraty istotnych szczegółów przekazu w trakcie jego powielania (typariusz - woskowy odcisk - odlew z odcisku). Wydaje się, że kwestię ewentualnej ingerencji rytownika w pierwotną postać sandomierskiego typariusza mogłyby rozstrzygnąć jego specjalistyczne badania fizykochemiczne. Ich przeprowadzenie jest zatem pilnym postulatem badawczym. 
(która w kilku innych miejscach legendy ma $4 \mathrm{~mm}$ ), a przy tym zachować między poszczególnymi literami po $1 \mathrm{~mm}$ odstępu (tyle wynoszą przeciętnie odstępy w tej inskrypcji), to otrzymalibyśmy idealnie regularny szereg liter słowa BOEMIE. Nieregularności występujące $\mathrm{w}$ inskrypcji napieczętnej są co prawda bardzo subtelne, ale zauważalne, nad czym - szczególnie wobec rozbieżności dotyczących identyfikacji klejnotu herbowego - nie można przejść do porządku dziennego. Poczynione obserwacje pozwalają przyjąć, że inskrypcja była przerabiana. Zapewne wraz z nią przerobiono także godło heraldyczne i zastąpiono orłem pierwotnie widniejącego tam w tarczy lwa czeskiego.

Stwierdziliśmy zatem, że na pieczęci sandomierskiej nie mamy do czynienia z klejnotem herbu Orzeł Biały, lecz z klejnotem władców czeskich, na co wskazują widoczne poniżej linii piór sercowate elementy (lipowe listki), a inskrypcja napieczętna została najprawdopodobniej przerobiona - pierwotne słowo BOEMIE zastąpiono słowem POLOnIE. Wniosek jest następujący - pieczęć wykonano dla miasta w czasach, gdy panował nad nim król czeski. Należy zatem odrzucić przyjmowane dotąd datowanie tłoka na lata 1320-1343. Te daty (biorąc pod uwagę inskrypcję przypisującą pieczęć królowi Polski) mogą tylko wyznaczać czas, w którym tłok przerobiono. Pozostaje jednak kluczowe pytanie: kiedy wykonano typariusz? Nim udzielimy odpowiedzi, musimy przypomnieć kontekst polityczny końca XIII w. ${ }^{59}$

Wraz ze śmiercią księcia Leszka Czarnego w 1288 r. rozpoczęły się zbiegi króla Wacława II o ziemię krakowską i sandomierską. Władca ten 1289 r. hołdem lennym podporządkował sobie księcia Kazimierza bytomskiego, w ten sposób otwierając sobie drogę na Kraków. W 1291 r. Wacław, porozumiawszy się z panami krakowskimi, którym wystawił w Litomyślu przywilej gwarantujący dotychczasowe prawa, zajął Kraków, a w następnym roku Sandomierz - skąd ustąpić musiał Władysław Łokietek, zmuszony następnie do uznania zwierzchnictwa władcy czeskiego nad wszystkimi swymi ziemiami. Jednocześnie w sojusz z Wacławem weszli w 1291 r. książęta górnośląscy, Bolesław opolski i Mieszko cieszyński. Realnym rywalem księcia czeskiego w procesie łączenia ziem polskich był wówczas Przemysł II, który w 1295 r., mimo sprzeciwu Wacława II, koronował się na króla Polski. Śmierć Przemysła w 1296 r. i nieudolne rządy księcia Władysława Łokietka, w wyniku których utracił on poparcie miejscowego rycerstwa, pozwoliły władcy czeskiemu, który wciągnął Łokietka w niekorzystną dla niego rozgrywkę dyplomatyczną, zająć w 1300 r. Wielkopolskę, Pomorze Gdańskie oraz dziedziczne ziemie Łokietka (Kujawy brzeskie, ziemie sieradzka i łęczycka). W efekcie Wacław II sięgnął w Gnieźnie, w początkach września 1300 r. ${ }^{60}$,

59 T. J u r e k, Polska pod władzą obcego króla. Rządy czeskie w latach 1291-1306, w: Król w Polsce XIV i XV wieku, Kraków 2006, s. 187-220; te nże, Dyplomatyka i łowy. Za kulisami układu klęckiego (1299), w: Miasta, ludzie, instytucje, znaki. Księga jubileuszowa ofiarowana Profesor Bożenie Wyrozumskiej w 75. rocznicę urodzin, Kraków 2009, s. 27-41; t e n ż e, Polska droga do korony królewskiej 1295-1300-1320, w: Proměna středovýchodní Evropy raného a vrcholného středověku. Mocenské souvislosti a paralely, Brno 2010, s. 171177; L. J a n, Václav II., s. 106-107, 146-148, 186-198; 225-232, 248-249, 273-274, 276-287 (w pracach tych dalsza literatura).

${ }^{60}$ Wrześniową datę koronacji przyjął ostatnio, korygując błędne datowanie gnieźnieńskiego aktu koronacyjnego na sierpień albo listopad, L. J a n, Znovu k datu hnězdenské 
po swoją drugą koronę - polską. Wcześniej bowiem koronował się już na króla czeskiego (2 VI 1297). Na wykonanej wówczas królewskiej pieczęci zaznaczył swoje zwierzchnictwo nad Krakowem i Sandomierzem (REX BOEMIE dVX CRACOVIE ET SANdOMERIE). Sandomierzem władał więc Wacław II, jako książę od 1292 do praskiej koronacji w 1297 r., jako król czeski i książę sandomierski do gnieźnieńskiej koronacji w 1300 r., a jako król czeski i polski od 1300 aż do swojej śmierci w 1305 r. Należy jednak pamiętać, że Wacław II także przed koronacją w Pradze tytułował się i był przez innych tytułowany królem czeskim, chociaż nie zamanifestował tego w legendzie używanej wówczas pieczęci (dOMInVS ET ERES REGNI BOEMIE) ${ }^{61}$.

Można przyjąć, że gdyby sandomierski tłok pieczętny powstał po koronacji Wacława II na króla Polski, w legendzie napieczętnej znalazłaby się zapewne podwójna tytulatura królewska. Napis zaś na typariuszu - jak przyjęliśmy - odnosił się pierwotnie tylko do godności króla Czech, co wyznacza datę powstania pieczęci na lata 1297-1300, a może nawet na lata 1292-1300, przy założeniu, że już przed 1297 r. możliwe było użycie wobec tego władcy określenia rex (S’ REGIS) w legendzie napieczętnej. Zaproponowane tu datowanie tłoka pieczętnego zaskakująco koresponduje z czasem wykonania pieczęci czeskiego miasta Žatec (SIGILLVM CIVITATIS ZACENSIS) ${ }^{62}$, znanej od 1295 r. Pieczęć tego miasta - co podkreślał już M. Rokosz - jest uderzająco podobna do pieczęci sandomierskiej, zarówno w zakresie liternictwa (majuskuła z półuncjalną literą T), jak też w warstwie obrazowej (niemal identyczne wyobrażenie - pieczęci žateckiej brak tylko hełmu z klejnotem, wieńczącego tarczę herbową). Badacz ten uznał nawet, że w przypadku obydwu tych pieczęci mamy do czynienia ze ścisłym naśladownictwem, bądź nawet z tą samą ręką lub warsztatem, choć nie odniósł się przy tym do kwestii czasu dzielącego obydwie realizacje. Zauważmy, że w inskrypcji žateckiej - podobnie jak w sandomierskiej - litera T występuje w dwóch formach, a litera $\mathrm{N}$ jest kapitałowa (jak na typariuszu sandomierskim, przed wprowadzeniem litery n w słowie POLOnIE). I jeszcze jedno - obydwie pieczęcie mają znaczną, jak na pieczęcie miejskie, średnicę: $75 \mathrm{~mm}^{63}$. Te podobieństwa nie mogą być li tylko kwestią przypadku, możliwe zatem, że pieczęć Sandomierza wykonano, wzorując się na pieczęci miasta Žatec, przy okazji koronacji Wacława II w 1297 r., manifestując w ten sposób związki króla czeskiego z miastem ${ }^{64}$.

T. Jurek, omawiając czasy rządów czeskich w Polsce, zwrócił uwagę, że Wacław II „ze swej strony bardzo starannie gromadził wszelkie tytuły legitymizujące jego rządy

korunovace krále Václava II., Časopis Matice moravské 131, 2012, s. 129-134; t e n że, Václav II, s. 282-285.

${ }^{61}$ Regesta diplomatica nec non epistolaria Bohemiae et Moraviae, t. II, wyd. J. Emler, Praha 1882, passim; zob. także J. Č a r e k, O pečetech, s. 17-18; J. H o m o lk a, K ikonografii, s. 175-177.

${ }^{62}$ J. Č a r e k, Městské znaky, s. 427-428 (fot. z zamienionym podpisem); M. R o k o s z, Sigillum, fot. na s. 314 (na s. 313 błąd literowy w zapisie nazwy miasta w legendzie: ZATENSIS).

${ }_{63} \mathrm{~W}$ niektórych opracowaniach średnicę pieczęci (na podstawie pomiaru odlewu) określono na 76 mm, zob. F. P i e k o s iń s k i, Pieczęcie, nr 363, s. 211; M. R o k o s z, Sigillum, s. 313. Tak przyjęli też wydawcy woskowego odcisku z 1422 r., chociaż stan jego zachowania nie pozwala na precyzyjny pomiar (Dokumenty strony polsko-litewskiej, s. 96, nr 115).

${ }_{64} \mathrm{~W}$ literaturze przedmiotu zwracano już uwagę na fakt sprzyjania przez Wacława II miastom, zob. ostatnio T. J u r e k, Polska pod władzą, s. 215-216. 
w Polsce” i korzystał z nich, powołując się „na rozmaite kategorie prawne”, czemu sprzyjać miały nieustabilizowane ówcześnie wyobrażenia „o istocie praw do tronu”65. Na podstawie wzmianek kronikarskich (Otacher ouz der Geul, Přibík Pulkawa) ${ }^{66}$ można przyjąć, że prawa do Krakowa i Sandomierza przekazała mu księżna Gryfina, wdowa po księciu Leszku Czarnym, ale - jak zauważył cytowany historyk - taki pogląd budzi „poważne zastrzeżenia, bowiem Gryfina jako księżna małżonka nie dysponowała przecież dziedzicznymi prawami do Małopolski”' ${ }^{\circ 7}$. Zauważmy jednak, że dyskutując ostatnio kwestię najstarszej sandomierskiej pieczęci miejskiej (ostroowalnej) - którą de facto uznać należy za pieczęć księżnej Kingi68, a nie pieczęć miejską - wskazano, że posłużenie się ową pieczęcią, jako contrasigillum pieczęci Leszka Czarnego w przywileju lokacyjnym z 1286 r. „zdaje się - - wynikać z faktu dysponowania przez księżne krakowskie uposażeniem w Sandomierzu" ${ }^{99}$. A jeśli tak, to może Wacław II wszedł w posiadanie praw do owego uposażenia, co wyjaśniałoby wspomniane wzmianki kronikarskie i tłumaczyłoby niespotykaną treść inskrypcji pieczęci wielkiej sandomierskiej: S' REGIS ET CIVITATIS. Legitymizowała ona króla czeskiego w roli współwłaściciela typariusza i współdecydenta spraw miasta, a miasto $\mathrm{w}$ roli reprezentanta władcy ${ }^{70}$.

65 Tamże, s. 195.

66 Tamże, s. 196, przyp. 43.

67 Tamże, s. 196.

${ }_{68}$ W literaturze przyjęto, że w związku z lokacją Sandomierza w 1286 r. wprowadzono do użytku pierwszą, ostroowalną pieczęć miasta. Znany był tylko jeden jej odcisk - pełniący rolę contrasigillum pieczęci księcia Leszka Czarnego - ale nie zachował się do naszych czasów. Obecnie dysponujemy jedynie jej przerysami z końca XVIII lub pierwszej połowy XIX w., wykonanymi z nieczytelnego już wówczas odcisku. Najnowsze badania pokazały, że jest to pieczęć księżnej Kingi, żony księcia Bolesława Wstydliwego, którego następcą był Leszek Czarny - zob. M. S tar zyńs ki, Uwagi w sprawie genezy najstarszej pieczęci Krakowa z XIII wieku (na marginesie ostatnich badań), Studia Źródłoznawcze 50, 2012, s. 32-34, ryc. 3-4; T. G i e r g i e 1, R. J o p, Dokument lokacyjny Leszka Czarnego dla Sandomierza z 1286 roku, Sandomierz 2015, s. 29-34, ryc. 6, 8-10; P. O k n i ń s k i, Główne etapy, s. 89-91, 105, ryc. 1-3 (w wymienionych pracach szczegółowa argumentacja i cała starsza literatura). Pomimo tego H. S e r o k a, Herby miasta królewskiego, s. 8-9, ryc. 6-7, nadal podtrzymuje dawną identyfikację, widząc tu najstarszą pieczęć miejską Sandomierza (autor ten nie zmienił swego stanowiska wyrażonego w starszej swojej pracy: Herby miast małopolskich, s. 22, ryc. 1).

${ }_{69}$ P. O k n iń s k i, Główne etapy, s. 91; nie wyklucza on, że jako contrasigillum pieczęci Leszka Czarnego z 1286 r. mogła zostać odciśnięta pieczęć księżnej Gryfiny, której wyglądu nie znamy. Wcześniej taką możliwość zasugerowali T. G i e r g i e 1, R. J o p, Dokument, s. 35, „o ile przyjęła ona wzorzec stempla swojej poprzedniczki”. Przegląd pieczęci księżnych z XIII w. dał J. P a k u ls ki, Zaginiona pieczęć księżnej mazowieckiej Perejesławy z 1276 r. a trzynastowieczne sigilla księżnych Polski dzielnicowej, w: Nihil superfluum esse. Studia z dziejów średniowiecza ofiarowane Profesor Jadwidze Krzyżaniakowej, Poznań 2000, s. 247-262.

70 Takie brzmienie legendy napieczętnej może wskazywać, że na wczesnym etapie ustrojowego rozwoju miast dopuszczano możliwość działania władz miejskich w imieniu nieobecnego władcy, zob. A. G ą s i o ro w s ki, Wójt i starosta. Ramię monarsze w polskim mieście średniowiecznym, w: Ars historia. Prace z dziejów powszechnych i Polski, Poznań 1976, s. 437-444. Zauważmy też, że w czasach Wacława II starostowie mogli dysponować pieczęciami o charakterze „królewskim”. Frycek z Čachovic pieczętował sygnetem, który określano jako annulum domini Wenceslai incliti regis Bohemie et Polonie (zob. T. J u r e k, Polska, s. 209-210; L. J a n, Václav II., s. 294 i 612, przyp. 27). 
Zgłoszone uwagi natury ikonograficznej i epigraficznej, niespotykana treść legendy napieczętnej, a także analogie z pieczęcią miasta Žatec - wszystko to skłania do przyjęcia poglądu, że sandomierski typariusz powstał w latach 1297-1300 (może 12921300). Przesuwamy więc wstecz datowanie pieczęci o co najmniej dwadzieścia lat i uznajemy, że powstała w czasach Wacława II, króla czeskiego, księcia krakowskiego i sandomierskiego ${ }^{71}$. Przerobienie pieczęci wielkiej Sandomierza datować należy na pewno na czas po koronacji Władysława Łokietka, a niewykluczone, że dopiero na 1343 r. Datowany na 15 VII 1343 r. dokument, przy którym przywieszono najstarszy znany nam odcisk tej pieczęci, wystawiły - na potwierdzenie pokoju kaliskiego miasta Kraków, Sandomierz i Nowy Sącz ${ }^{72}$. W innym dokumencie z 8 VII 1343 r. gwarantem były miasta Poznań, Kalisz, Włocławek i Brześć ${ }^{73}$. Jeśli pieczęć wielka Sandomierza nie została już wcześniej zaktualizowana (a to mogło się przecież wydarzyć), miasto zaś posługiwało się innym, mniej reprezentacyjnym sigillum ${ }^{74}$, to właśnie okoliczności 1343 r. mogły skłonić władze miejskie do przerobienia starego typariusza, nieaktualnego już w zakresie treści ideowych. Powodem tego kroku mogła być chęć przywieszenia pieczęci godnie reprezentującej miasto, która swym splendorem nie ustępowałaby pieczęciom pozostałych miast sygnatariuszy wystawianych dokumentów. Te były zaś imponujących rozmiarów (Kraków: $65 \mathrm{~mm}$; Poznań: $67 \mathrm{~mm}$; Nowy Sącz: 65 mm; Kalisz: 58 mm; Brześć Kujawski: 70 mm) oraz złożone w zakresie treści ideowych, w których odwoływały się do wizerunku murów i baszt miejskich (Kraków, Poznań, Kalisz, Włocławek, Brześć Kujawski) lub kościoła (Nowy Sącz), do przedstawień świętych patronów (Kraków, Poznań, Nowy Sącz), a także do wyobrażeń herbowych (Kraków, Poznań, Włocławek). Być może władze miejskie Sandomierza, nie dysponując wówczas pieczęcią, która właściwie oddawałaby, ich zdaniem, realne znaczenie miasta, zdecydowały się na wykorzystanie dawnego typariusza z czasów czeskiego panowania Wacława II. Przeróbce poddano jak przyjęliśmy - fragment inskrypcji (słowo: BOEMIE $^{75}$ na POLOnIE) i zastąpiono

${ }^{71}$ Zakładana przez nas pierwotna legenda (S’ REGIS BOEMIE ET CIVITATIS SANDOMIRIE) wskazywałaby (podobnie jak legenda królewskiej pieczęci Wacława II z 1297 r.), że ziemie zajmowane przez władcę czeskiego przed jego koronacją w 1300 r. traktowane były jako przyłączone do Czech.

${ }_{72}$ Kodeks dyplomatyczny Polski, t. I, nr 111.

73 Kodeks dyplomatyczny Wielkopolski, t. II, [wyd. I. Zakrzewski], Poznań 1878, nr 1222.

${ }^{74} \mathrm{O}$ kancelarii miejskiej przed połową XIV w. i o używaniu pieczęci miejskich niewiele wiadomo, zob. ostatnio P. O k n i ń s k i, Główne etapy, s. 97-98. Poza rzekomą, ostroowalną pieczęcią miejską z XIII w., o której była już mowa (zob. przyp. 68-69), znamy jeszcze pieczęć mniejszą oraz ławniczą, których powstanie jest datowane ogólnie na czasy panowania Kazimierza Wielkiego - M. H a i s i g, Nieznana pieczęć miasta Sandomierza, Miesięcznik Heraldyczny 17, 1938, z. 9, s. 134-135; M. G u m o w s k i, Najstarsze pieczęcie, s. 193-194, tabl. XXX/383-384; H. S e r o k a, Herby miast małopolskich, s. 104; t e n ż e, Herby miasta królewskiego, s. 12, fot. 9-11. Fakt istnienia znanej nam pieczęci mniejszej (z napisem: S'MInVS CIVITATIS SAnDOMIRIE), sugeruje równoczesne funkcjonowanie pieczęci większej, ale skoro nie wiemy, kiedy wykonano owo sigillum minus, to nie możemy wykluczyć, że stało się to po przerobieniu typariusza pieczęci wielkiej Sandomierza lub w tym samym czasie.

75 Zaznaczmy tu, że tak właśnie oddana nazwa Czech znalazła się na wszystkich trzech pieczęciach Wacława II (J. Č a r e k, O pečetech, s. 17-19; J. H o molk a, K ikonografii, s. 175-178). 
królewskim, ukoronowanym orłem lwa czeskiego, widniejącego zapewne pierwotnie w tarczy, pozostawiając jednak stary klejnot czeskiego władcy. Zleceniodawcy przeróbki typariusza mogli uznać, że pozostawienie tego klejnotu będzie akceptowalne wobec podobieństwa do klejnotu z książęcego herbu kujawskiego. Tak wykreowane wyobrażenie heraldyczne było jednak treściowo bałamutne, łączyło bowiem w jeden znak elementy - bądź co bądź - dwóch różnych, królewskich herbów, i kto wie, czy nie z tej właśnie przyczyny pieczęć sandomierska była tak incydentalnie używana ${ }^{76}$. Z czasów Kazimierza Wielkiego nie znamy żadnych innych przykładów jej zastosowania. Po ujawnieniu tego dysonansu ideowego zapewne poniechano jej używania w okresie piastowskim, incydentalnie powracając do niej dopiero w 1422 r., znów przy wyjątkowej okazji zawarcia pokoju z Krzyżakami.

\section{BIBLIOGRAFIA}

Adamczyk B., Pieczęcie miast małopolskich do XV w., w: Acta Universitatis Wratislaviensis, Historia XXXIII, Wrocław 1980.

Baliński M., Lipiński T., Starożytna Polska pod względem historycznym, jeograficznym i statystycznym opisana, t. II, Warszawa 1844.

Čarek J., Městské znaky v českých zemích, Praha 1985.

Čarek J., O pečetech českých knížat a králů z rodu Přemyslova, Sborník příspěvků k dějinám hlavního města Prahy 8, 1938.

Csapodi-Gárdonyi K., Iluminowane kodeksy europejskie, Wrocław 1984.

Eörsi A., Gotyk międzynarodowy, Warszawa 1986.

Gąsiorowski A., Wójt i starosta. Ramię monarsze w polskim mieście średniowiecznym, w: Ars historia. Prace z dziejów powszechnych i Polski, Poznań 1976.

Giergiel T., Jop R., Dokument lokacyjny Leszka Czarnego dla Sandomierza z 1286 roku, Sandomierz 2015.

Gumowski M., Handbuch der polnischen Siegelkunde, Graz 1966.

Gumowski M., Najstarsze pieczęcie miast polskich XIII i XIV wieku, Toruń 1960.

Haisig M., Herb miasta Sandomierza, Wrocław 1973.

Haisig M., Nieznana pieczęć miasta Sandomierza, Miesięcznik Heraldyczny 17, 1938.

Haisig M., Studia nad legendą pieczęci miejskiej, Wrocław 1953.

Heymowski A., Les cimiers médiévaux de la chevalerie polonaise, w: Le cimier mythologique, rituel, parenté des origines au XVI ${ }^{\mathrm{e}}$ siècle, Bruxelles 1990.

Heymowski A., Les cimiers médiévaux des blasons polonais, w: Recueil du IX ${ }^{\mathrm{e}}$ Congrès international des sciences généalogiques et héraldiques, Berne 1968.

Hlebionek M., Pieczęcie Piastów kujawskich, Inowrocław 2011.

Homolka J., K ikonografii pečetí posledních Přemyslovců, w: Umění doby posledních Přemyslovců, Praha 1982.

Jan L., Václav II. Král na strribrném trůnu 1283-1305, Praha 2015.

Jan L., Znovu k datu hnězdenské korunovace krále Václava II., Časopis Matice moravské 131, 2012.

Jaworska A., Konotacje herbu Orzeł Biały w sfragistyce monarchów z dynastii Piastów i Jagiellonów (1295-1572), w: Pieczęć w Polsce średniowiecznej i nowożytnej. Zbiór studiów, Lublin 1998.

Jaworska A., Orzeł Biały. Herb państwa polskiego, Warszawa 2003.

${ }^{76}$ Zauważył to M. R o k o s z, Sigillum, s. 320: „Mogą wreszcie zastanawiać jedynie dwa zachowane okazy naszej pieczęci, co świadczyłoby o oszczędnym nią szafowaniu i używaniu jej w wyjątkowych okolicznościach wyższej wagi prawnej”. 
Jurek T., Dyplomatyka i łowy. Za kulisami układu klęckiego (1299), w: Miasta, ludzie, instytucje, znaki. Księga jubileuszowa ofiarowana Profesor Bożenie Wyrozumskiej w 75. rocznicę urodzin, Kraków 2009.

Jurek T., Polska droga do korony królewskiej 1295-1300-1320, w: Proměna středovýchodní Evropy raného a vrcholného středověku. Mocenské souvislosti a paralely, Brno 2010.

Jurek T., Polska pod władzą obcego króla. Rządy czeskie w latach 1291-1306, w: Król w Polsce XIV i XV wieku, Kraków 2006.

Kaczmarek R., Portal z tympanonem w fasadzie wschodniej ratusza we Wrocławiu. Przyczynek do ikonografii lwa w hełmie, w: Nobile claret opus. Studia z dziejów sztuki dedykowane Mieczysławowi Zlatowi, Wrocław 1998.

Kajzer L., Jeszcze o Sali gotyckiej w domu przy Rynku Głównym 17 w Krakowie, Biuletyn Historii Sztuki 36, 1974, z. 4.

Kajzer L., Uzbrojenie i ubiór rycerski w średniowiecznej Małopolsce w świetle źródeł ikonograficznych, Wrocław-Warszawa 1976.

Katalog zabytków sztuki w Polsce, t. IV, z. 10, Warszawa 2005.

Krása J., Rukopisy Václava IV, Praha 1974.

Kuczyński S. K., Les cimiers territoriaux en Pologne médiévale, w: Le cimier mythologique, rituel, parenté des origines au XVI ${ }^{\mathrm{e}}$ siècle, Bruxelles 1990.

Kuczyński S. K., Polskie herby ziemskie. Geneza, treści, funkcje, Warszawa 1993.

Maráz K., Pečeti Jana Lucemburského, Brno 2007.

Michta J., Klejnot w herbach w średniowieczu i okresie nowożytnym, w: Venerabiles, nobiles et honestii. Studia z dziejów społeczeństwa Polski średniowiecznej. Prace ofiarowane Profesorowi Januszowi Bieniakowi w siedemdziesiątą rocznicę urodzin i czterdziestopięciolecie pracy naukowej, Toruń 1997.

Nadolski A., Uroczysty strój rycerski królów polskich w XIV-XV wieku, Kwartalnik Historii Kultury Materialnej 21, 1973.

Neubecker O., Heraldry: Sources, Symbols and Meaning, London 1997.

Okniński P., Główne etapy formowania się miasta lokacyjnego w Sandomierzu w XIII-XIV wieku, Roczniki Historyczne 82, 2016.

Orzeł Biały - 700 lat herbu państwa polskiego, Warszawa 1995.

Pakulski J., Zaginiona pieczęć księżnej mazowieckiej Perejesławy z 1276 r. a trzynastowieczne sigilla księżnych Polski dzielnicowej, w: Nihil superfluum esse. Studia z dziejów średniowiecza ofiarowane Profesor Jadwidze Krzyżaniakowej, Poznań 2000.

Pastoureau M., L'art héraldique au Moyen Âge, Paris 2009.

Paszkiewicz B., De moneta in Regno currente. Mennictwo polskie Kazimierza Wielkiego, Roczniki Historyczne 74, 2008

Paszkiewicz B., Denar Władysława Łokietka z tarczą, Wiadomości Numizmatyczne 46, 1994, z. 1 .

Paszkiewicz B., Denary krakowskie Władysława Łokietka - uzupełnienia, Wiadomości Numizmatyczne 36, 1992, z. 3-4.

Paszkiewicz B., Kraków, Sandomierz i mennictwo Władysława Łokietka, w: Miasta, ludzie, instytucje, znaki. Księga jubileuszowa ofiarowana Profesor Bożenie Wyrozumskiej w 75. rocznicę urodzin, Kraków 2009.

Paszkiewicz B., Mennictwo Władysława Łokietka, Wiadomości Numizmatyczne 30, 1986, z. 1-2.

Paszkiewicz B., Nieznany denar książęcy Władysława Łokietka, Wiadomości Numizmatyczne 54, 2010, z. 1.

Paszkiewicz B., Od symbolu do herbu. Orły polskie na monetach średniowiecznych, w: Orzeł Biały. Herb państwa polskiego, Warszawa 1996.

Piech Z., Ikonografia pieczęci Piastów, Kraków 1993.

Piech Z., rec., Kwartalnik Historyczny 102, 1995.

Piech Z., Symbole władcy i państwa w monarchii Władysława Łokietka i Kazimierza Wielkiego, w: Imagines potestatis. Rytuały, symbole i konteksty fabularne władzy zwierzchniej. Polska X-XV w., Warszawa 1994. 
Piech Z., Uwagi o genezie i symbolice herbu książąt kujawskich, Studia Historyczne 30, 1987. Piech Z., Zbiory odlewów pieczęci w Zakładzie Nauk Pomocniczych Historii Uniwersytetu Jagiellońskiego, w: Zbiory pieczęci w Polsce, Warszawa 2009.

Piech, Strój, insygnia i atrybuty książąt piastowskich do końca XIV wieku (cz. II), Kwartalnik Historii Kultury Materialnej 38, 1990, nr 3-4.

Piekosiński F., O sali gotyckiej w kamienicy Hetmańskiej w Krakowie, Rocznik Krakowski 9, 1907.

Piekosiński F., Pieczęcie polskie wieków średnich, cz. I: Doba piastowska, Kraków 1899.

Piekosiński F., Sala gotycka w kamienicy Hetmańskiej w Krakowie, Rocznik Krakowski 1, 1898.

Pietrzak J., Średniowieczne hełmy garnczkowe na ziemiach polskich na tle zachodnioeuropejskim, Bytom 2005 (Rocznik Muzeum Górnośląskiego w Bytomiu, Archeologia 16).

Piwowarczyk E., Mieszczańska „katedra”. Patronat nad kościołem Mariackim w średniowieczu, Nasza Przeszłość 97, 2002.

Rokosz M., Sigillum regis... et civitatis. O pieczęci wielkiej Sandomierza, w: Heraldyka i okolice, Warszawa 2002.

Sedláček A., Atlasy erbů a pečetí české a moravské středověké šlechty, t. II, Praha 2001.

Sedlak V. J., O klenotu českého znaku, Rodokmen 1, 1946.

Seroka H., Herby miast małopolskich do końca XVIII wieku, Warszawa 2002.

Seroka H., Herby miasta królewskiego Sandomierza, Sandomierz 2016.

Seroka H., W sprawie edycji pieczęci miast dawnej Polski, w: Pieczęcie dawnej Rzeczypospolitej. Stan i perspektywy badań, Warszawa 2006.

Sfragistyka, Warszawa 1960.

Skubiszewski P., Die Schlusssteine des Saales im Krakauer Haus Marktplatz 17, w: Die Parler und der Schöne Stil 1350-1400. Europäische Kunst unter den Luxemburgen. Ein Handbuch zur Ausstellung des Schnütgen-Museums in der Kunsthalle Köln, t. II, Köln 1978

Sobieszczański F. M., Wiadomości historyczne o sztukach pięknych w dawnej Polsce, t. I, Warszawa 1847.

Starzyński M., Uwagi w sprawie genezy najstarszej pieczęci Krakowa z XIII wieku (na marginesie ostatnich badań), Studia Źródłoznawcze 50, 2012.

Szymański J., Herbarz średniowiecznego rycerstwa polskiego, Warszawa 1993.

Szymański J., W sprawie genezy polskich herbów miejskich, w: Społeczeństwo Polski średniowiecznej, t. VI, Warszawa 1994.

Śnieżyńska-Stolot E., Andegaweńskie dary złotnicze z herbami polskimi w Kaplicy Węgierskiej w Akwizgranie, Folia Historiae Artium 11, 1975.

Walczak M., Dekoracja heraldyczna pałacu przy Rynku Głównym 17 w Krakowie, Folia Historiae Artium, seria nowa 10, 2005.

Walczak M., Rzeźba architektoniczna w Małopolsce za czasów Kazimierza Wielkiego, Kraków 2006.

Węcławowicz T., Dekoracja figuralna prezbiterium kościoła Mariackiego w Krakowie a zagadnienie mecenatu Mikołaja Wierzynka Starszego, Rocznik Krakowski 56, 1990.

Znamierowski A., Dudziński P., Wielka księga heraldyki, Warszawa 2008.

Znamierowski A., Elementy herbu polskiego 1295-1995, w: Orzeł Biały. Herb państwa polskiego, Warszawa 1996.

\section{Once again on the great seal of the city of Sandomierz}

\section{Summary}

The great seal of the city of Sandomierz is known from the preserved impressions of 1343 and 1422, and the preserved matrix. Its analysis makes it possible to assume that originally the field of the seal displayed a heraldic shied crowned with a helmet with the crest showing 
the Bohemian lion, while the inscription around it read: S' REGIS BOEMIE ET CIVITATIS SANDOMIRIE. The matrix was made between 1297 and 1300 (or maybe 1292-1300), when Sandomierz was in the hands of the Czech ruler Wenceslaus II. During the years 1320-1343 (the times of Władysław the Short and Kazimierz the Great) the matrix was redesigned. The lion in the heraldic shield was replaced with the royal eagle (White Eagle) and the word BOEMIE in the inscription was replaced with the word POLOnIE. Over the heraldic shield with the eagle, however, the crest from the Czech coat-of-arms was retained (an eagle's wing). 

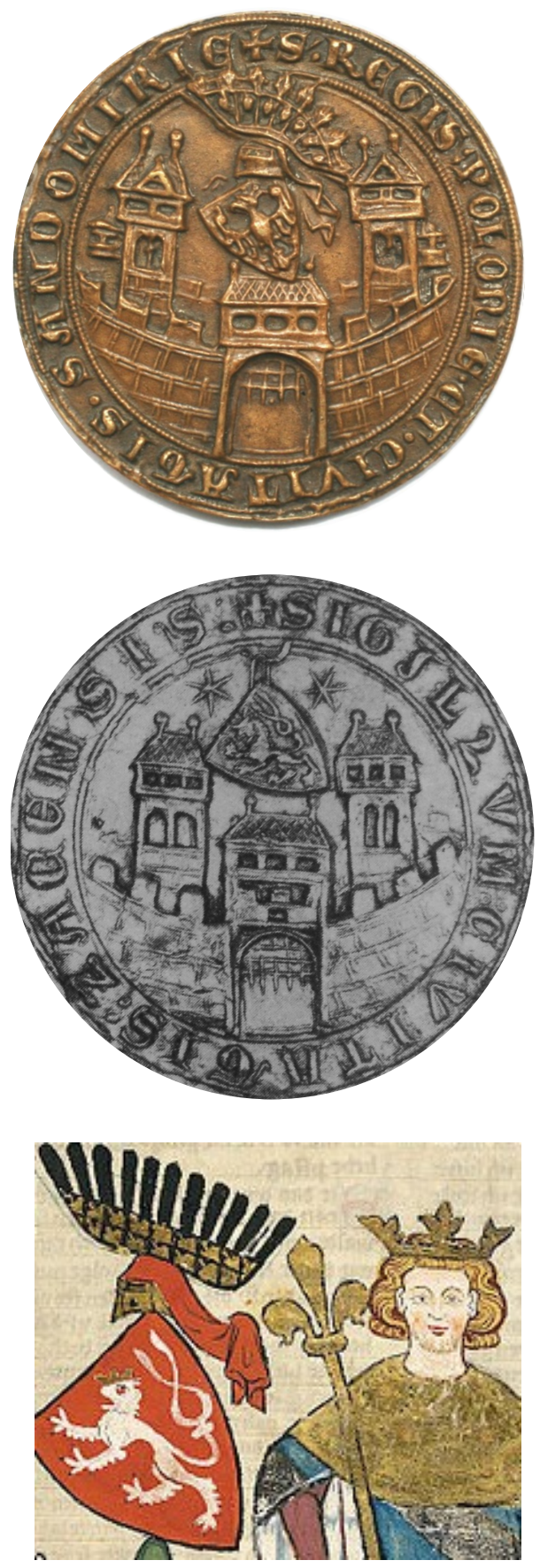

Tablica I: 1) Pieczęć wielka miasta Sandomierza; odlew ze zbiorów Zakładu Nauk Pomocniczych Historii UJ, sygn. D 336 (fot. ZNPH UJ); 2) Pieczęć miasta Žatec (za: J. Čarek, Městské znaky, s. 428); 3) Fragment miniatury z przedstawieniem króla czeskiego Wacława II, Codex Manesse, k. 14r (za: <http://digi.ub.uni-heidelberg.de/diglit/cpg848/0015>) 

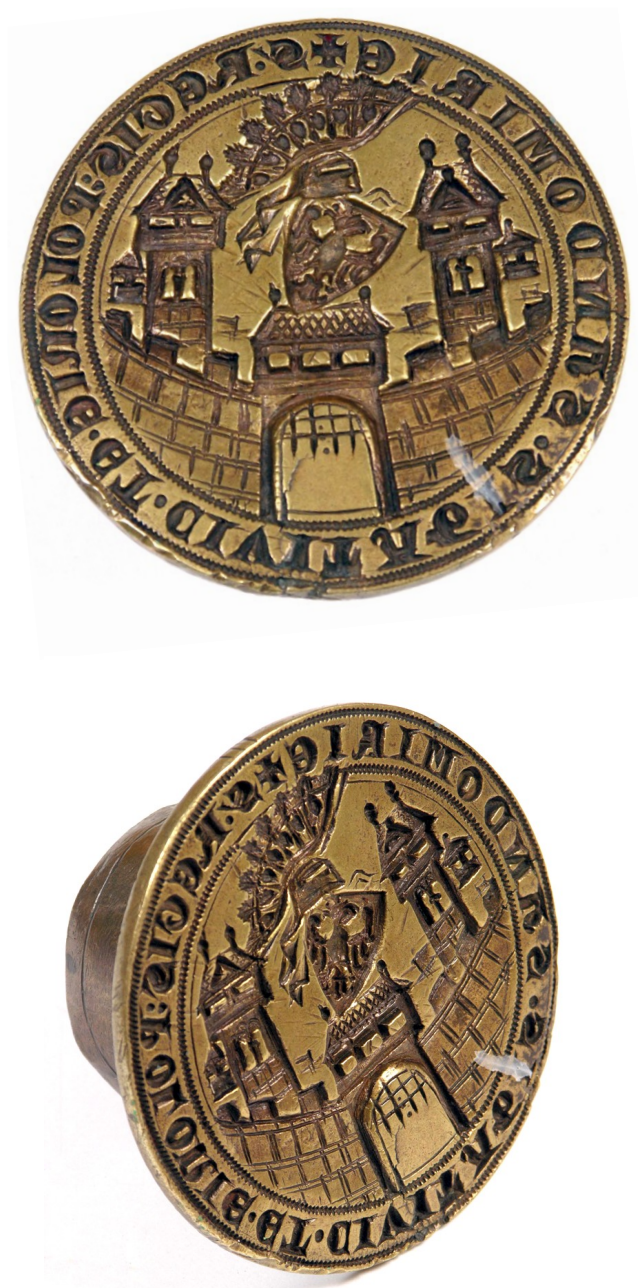

Tablica II: 4-5) Typariusz pieczęci wielkiej miasta Sandomierza ze zbiorów Muzeum Narodowego w Krakowie, sygn. MNK-MKCz XIII-1735 (fot. Pracownia Fotograficzna MNK) 